\title{
The Effect of Managing Distance Learning Educational Platforms on the Achievement of Secondary School Students in Chemistry in Jordan
}

\author{
Dr. BILAL JAFFAL MOHAMMAD ABUKDEIRI \\ Mr. HUTHAIFA AS'SD MOHAMMAD ALTARAWNEH \\ AHMAD TAHSEEN MOUSA ALTARAWNEH Mr.
}

\begin{abstract}
The study aimed to identify the effect of Managing distance learning educational platforms on the achievement of secondary school students in chemistry in Jordan. To achieve the objective of the study, the descriptive approach was used by constructing a questionnaire, and its validity and reliability were verified. The study sample consisted of (2019) male and female students. The study identified the following results: There was a statistically significant effect for the impact of managing educational platforms on Secondary students taught through distance learning on the total score in academic achievement and that effect accounted for $(64.8 \%)$ of the achievement. As for aspects, the results showed a statistically significant effect of the student-related and teacher-related aspects on academic achievement, and the lack of an effect of aspects related to the technical aspect. The results also showed the high effectiveness of educational platforms for students in the secondary stage during the distance learning with its various platforms in the kingdom ,and the "student" -related aspect ranked first, and in the second place came technical - related aspect, and in the third and last place came teacher - related aspects. The results also showed that there were statistically significant differences in the effectiveness of high school students during distance learning on the total degree and aspects according to the variables (educational platform, gender, grade) and the differences were in favor of females, the second secondary grade and Darsak platform .In light of the results, a number of recommendations were presented, the most important of which were: The necessity of encouraging secondary school students, especially the second secondary to follow the educational platforms to promote achievement, and to understand the educational materials ,And to lessen dependence on financially strained private lessons for students' families and training teachers on the optimal use of distance learning which has become a requirement of the current era.
\end{abstract}

Keywords: Educational platforms, distance learning, Chemistry.

DOI: $10.7176 / \mathrm{JEP} / 12-26-06$

Publication date:September $30^{\text {th }} 2021$

\subsection{INTRODUCTION}

Today, the world is witnessing a great technical and technological revolution, with its obvious affects all aspects of political, social, economic and educational life in particular. This necessitated the introduction of radical and tangible modifications in the educational policies and plans of countries, their ways of thinking, and ways to solve problems. The technical development and modern communications have helped to think seriously of reconsidering the formation of the educational institution by providing new environments and approaches of learning, which paved the way for the emergence of a type of learning patterns, which is e-learning. (Zain El-Din, 2006). Educational institutions, therefore are seeking to achieve their goals and achieve the task incumbent upon them. It has become obligatory for them to engage in the process of distance learning, use educational platforms, and search for the best way to transfer knowledge and communicate with students and teachers, and the easiest to use to improve the educational process, which directly affects the development of societies.

The spread of the Corona virus pandemic has forced countries around the world to close schools, affecting 103 million students across the Middle East and North Africa region. In past mid-March, Jordan was among the first countries in the region responding to the crisis by imposing curfews and closing all educational institutions in the Kingdom. In order to sustain learning during the pandemic, the Ministry of Education resorted to distance learning tools, as officials were quick to take advantage of the materials available in the private sector to develop an educational gate called "Darsak""As well as two TV channels dedicated to provide online lectures. These resources cover the main subjects included in the curriculum, which are Arabic, English, mathematics and science for grades from the first grade to the second secondary.

Distance learning is a type of learning that provides educational and training opportunities to the learner without direct supervision from the teacher, and without committing to a specific time and place for those who cannot complete the study or hindered by work from attending formal education. It is not considered a substitute for traditional education but rather a complementary to it. It is performed under the supervision of an educational institution responsible for preparing educational materials (Salem, Al-Qathani, 2013)

As Al-Azzam (2015) defined it as what the learner acquires as he interacts with educational experiences 
through different media, with which the learner interacts. The essence learning is acquired by the learner himself while interacting with educational situations directly without mediation .In the case of distance learning, the learner interacts with educational experiences through virtual media so that he can communicate with educational resources that are not in front of him in a lively way. Consequently, he is forced to resort to technological media that enable him to communicate and interact positively in order to continue the learning process through the multiple sources. Modern technology maximizes the source of learning and facilitates its acquisition and places it in the cognitive, emotional or skill structures.

There is no doubt that teaching chemistry requires an ability to imagine and visualize for both the teacher and the student because we deal with an invisible world, which is the world of atoms and molecules, and therefore we need an extra ability to Imagine to describe the relationships of atoms with each other to form molecules as well as molecules with each other to form compounds. This requires a lot of visualization and mental imagination, and we need many means of illustrations to approximate these concepts that a chemistry teacher needs. Therefore, there is necessity to a great development in the educational aids to assist students and teachers. Since the traditional education is done by filling the board with interaction mechanics, theories, diagrams and molecular structures of compounds that consumes time and effort to draw, as well as the wall charts and models as available illustrations, but they are not sufficient because the student exerts another effort to transform the explanations and notes from the teacher into pictures without benefiting from the teacher's educational experience. However, through computers, we were able to utilize their potentials- when implemented with high efficiency- we will find before us a new and enormous world of superior capabilities to form these illustrative means, which clarifies a lot of chemical concepts easily and conveniently.

The challenge that the world is facing today and the rapid changes that have occurred in all areas of life with the spread of the Corona virus involved all parts of the educational process in a sudden use of distance learning with its various platforms to ensure the continuity of the educational process, so everyone initially has experienced the shock of transportation to learn from the actual rooms to the virtual rooms.

\subsection{STUDY PROBLEM AND QUESTIONS:}

In Jordan, many young people have access to the Internet, but comprehensive access has not yet been achieved. So More than $16 \%$ of students in Jordan lack access to the Internet, which is 16 percentage points lower than the OECD average, and a third of them do not have a computer that can be used for school assignments, which is 25 percentage points lower than the OECDB inch mark average. in more detail, it appeared that this digital divide is often found in low-income families; Less than 30\% of students in lower income groups have a computer for homework, and only about $50 \%$ have access to the Internet. All of these reasons have led to concern about the challenges and obstacles that students encounter in general, and those at secondary stage in particular, because it is a crucial stage in the life of any student to determine his future. Also, distance learning is still a new experience, and the platforms are few, so it is necessary to get feedback from students to assure excellent learning.

\subsection{STUDY QUESTIONS:}

THE STUDY SEEKS TO ANSWER THE FOLLOWING QUESTIONS:

1. WAS THERE A STATISTICALLY SIGNIFICANT EFFECT AT THE LEVEL (0.05) $\geq A)$ FOR THE IMPACT OF MANAGING DISTANCE LEARNING EDUCATIONAL PLATFORMS ON SECONDARY STAGE STUDENTS IN ACADEMIC ACHIEVEMENT IN CHEMISTRY?

2. WHAT WAS THE EFFECT OF MANAGING EDUCATIONAL PLATFORMS IN DISTANCE LEARNING AND EDUCATION IN JORDAN?

3. WERE THERE ANY STATISTICALLY SIGNIFICANT DIFFERENCES AT THE LEVEL $(0.05 \geq$ A) FOR THE IMPACT OF MANAGING DIFFERENT EDUCATIONAL PLATFORM SON SECONDARY STAGE STUDENTS DURING DISTANCE LEARNING WITH ITS DIFFERENT PLATFORMS ASCRIBED TO THE VARIABLES (GENDER, GRADE, EDUCATIONAL PLATFORM)?

\subsection{SIGNIFICANCE OF THE STUDY:}

1. Contribution to the mechanism of designing educational programs and platforms and how to improve the teaching they provide to secondary stage students .

2. The importance of this study is that it is one of the studies that dealt with the topic of distance learning in light of the spread of the Corona Virus Impact on achievement in chemistry.

3. It is useful to know the training programs that teachers must master to carry out the distance learning process.

4. It gives feedback to all those interested in the field of learning and teaching regarding the developments of the status quo and the mechanism of teaching that has been achieved through distance learning with 
its various platforms for secondary students in chemistry.

\subsection{PROCEDURAL DEFINITIONS:}

- DISTANCE LEARNING: It is the learning that occurs when there is a distance between the teacher and the learner where pre-prepared educational platforms and materials are used, and the learners are separated from their teachers in time and place, or both. It is either synchronous or asynchronous teaching. And here we mean the learning that takes place through educational platforms (Darsak platform, Al hadaf Academy, Microsoft, others).

- EDUCATIONAL PLATFORMS: An interactive learning environment that employs web technology and combines the advantages of electronic content management systems and social networks such as face book, Twitter. They enable teachers to publish lessons and goals, set assignments, implement educational activities, communicate with teachers through multiple technologies, divide students into work groups, and help exchange ideas and opinions between teachers and students. Furthermore, they provide scientific content sharing, which helps to achieve high quality educational outcomes.

- SECONDARY STAGE :The duration of this stage in the normal situation is two years; where students are divided according to their choices into different fields that determine later the specializations that can be studied in universities, where a form is distributed to students to fill out according to the desired fields, then a study is made of the requests and choices followed by the distribution of students according to grades and their academic level to reach the required number, and at the end of this stage, an exam is taken separate from the school exams, called the general secondary exam. It is accurate, and among the curricula that are taught during the semester and supervised by the Ministry of Education and depending on the result, students are accepted in university majors.

- CHEMISTRY: It is a course that deals mainly with the chemistry curriculum, and it addresses the importance of chemistry in general and its role in our daily life. It enumerates briefly chemistry parts. In addition, it tackles secondary stage guidelines of chemistry as a core course to pass this stage

\subsection{THE LIMITS OF THE STUDY:}

THE LIMITS OF THIS STUDY WERE AS FOLLOWS:

OBJECTIVE LIMITATIONS: this study is confined to the effect of Managing distance learning educational platforms on the achievement of secondary stage students in chemistry in Jordan.

- TIME LIMITATIONS :This study was limited to the second semester of the academic year 2021/2020.

- SPATIAL LIMITATIONS: This study was limited to secondary schools in Karak Directorates of education.

\subsection{PREVIOUS STUDIES:}

(Miqdadi, 2020) The current study aimed to reveal the perceptions of secondary stage students in government schools in Jordan for the use of distance learning in light of the Corona virus crisis and its developments, and to identify the significance of the differences in the secondary stage students' perceptions with regard to the use of distance learning in Jordan according to the gender variable. The study was applied in the second semester of $2020 \mathrm{AD}$, and the descriptive survey method was used. The study population consisted of secondary school students in government schools in Irbid District, and the study sample consisted of (167) male and female students. The number of male sample was (89), and the number of females was (78) and chosen by simple random method. The study concluded the following results: - The arithmetic means ranged between (60.3-78.4), where item (1) which states, "Distance learning enriches my education" came in the first place, with a mean of (78.49), while item (19) which states " it helped eliminate many of students' problems" in the last place with arithmetic means (60.3) and a standard deviation (588) to a very large degree for the gender variable (males, females), there were no differences in the estimates of the sample individuals on the averages of the tool as a whole.According to the results. The researcher provided the following recommendations: - Conducting more studies and research on different samples and stages .Providing adequate support to the Ministry of Education in order to maintain its continuity and its ability to manage distance learning.Supporting for national projects that develop the idea of distance learning, and enhancing cooperation between it and the Jordanian Ministry of Education. Keywords: distance learning, secondary stage students, Corona crisis.

(Koch, 2020) The study aimed to identify the damage to education during the Covid-19 pandemic where many educational institutions closed their doors to contain the spread of infection, and to provide maintenance of learning through (distance and online education). This paper aims to explore the challenges teachers faced during distance learning in emergency situations so that others can learn by comparing these international experiences. This international study was based on teachers' experience and compared how education continue in Bahrain, Iraq and Russia. Researchers collected opinions and personal experiences using Zoom interviews, and then 
supported them with documentary evidence. The paper explored the experience dealing with the changes imposed by the global emergencies due to the pandemic, and its impact on the continuity of teaching and learning programs. The paper's findings conclude that while teachers and students struggled at the beginning of the (distance learning) experience and were often unprepared for such a sudden experience, there were also problems with electricity supply, stable Wi-Fi, or availability of computers. Such challenges have not affected most countries' ability to sustain education and learning services for students or impeded significantly their access to these services. The experience in the past months since the start of the pandemic had also achieved a mix of direct (distance education and distance learning) approach via the internet. The paper showed that there were cumulative advantages in promoting technology knowledge for those who are interested, as well as in reevaluating the importance of social relations in teaching and learning. The early evidence in this study also indicated the existence of gaps and disparities among the classes of society as far as access to education was concerned. Finally, the researchers emphasized that the challenges facing the education sector in global emergencies fall into three main categories: Crisis management and decision-making, infrastructure readiness, and student acceptance to the sudden change process. They also asserted that there was a real opportunity for a hybrid approach in the educational learning process that mixes face-to-face education with online learning, and that it may be the way forward for the "new era" beyond the epidemic.

\subsection{METHODOLOGY:}

The study adopted the descriptive approach for its suitability to achieve its goal.

\subsubsection{STUDY POPULATION:}

The study population consisted of all secondary school students in government secondary schools in the directorates of Education in Karak Governorate, whose number was (6732) male and female students, of whom (2826) were male and (3906) were female. (3098) were in the first secondary grade and (3634) in the second secondary grade, according to the statistics of the Planning Department in the Directorates of Education in Karak Governorate.

\subsubsection{THE STUDY SAMPLE:}

A stratified random sample of (0.30) was selected from the study population, the size of the study population was (2019) male and female students, question naires were distributed to them electronically, and were retrieved and subjected to statistical analysis, and Table No. (1) shows the characteristics of the study sample:

TABLE (1): THE CHARACTERISTICS OF THE STUDY SAMPLE.

\begin{tabular}{|c|c|c|c|}
\hline VARIABLE & VARIABLE TYPES & NUMBER & PERCENTAGE \\
\hline \multirow{3}{*}{ CLASSROOM } & 1ST SECONDARY & 929 & $46.01 \%$ \\
\hline & 2ND SECONDARY & 1090 & $53.98 \%$ \\
\hline & TOTAL & 2019 & $100.00 \%$ \\
\hline \multirow{3}{*}{ GENDER } & MALE & 847 & $41.97 \%$ \\
\hline & FEMALE & 1172 & $58.02 \%$ \\
\hline & TOTAL & 2019 & $100.00 \%$ \\
\hline \multirow{5}{*}{$\begin{array}{l}\text { EDUCATIONAL } \\
\text { PLATFORM }\end{array}$} & DARSAK & 1289 & $63.84 \%$ \\
\hline & AL HADAF ACADEMY & 215 & $10.64 \%$ \\
\hline & MICROSOFT TEAM & 207 & $10.25 \%$ \\
\hline & OTHER & 308 & 15 th. $25 \%$ \\
\hline & TOTAL & 2019 & $100.00 \%$ \\
\hline
\end{tabular}

\subsubsection{THE VALIDITY OF THE STUDY TOOL:}

The validity of the tool was verified by using the validity of the arbitrators. The questionnaire was shown to (6)specialists in technology of education in Jordanian universities to identify their opinions and suggestions regarding the appropriateness of the scale items in terms of language and its measurement to what it was designed for.

$(85 \%)$ was or above adopted to delete, keep or modify the items, and their comments were taken into account.

\subsubsection{RELIABILITY OF THE STUDY TOOL:}

The reliability of the study tool was verified using the stability of internal consistency by applying the Cronbach's reliability equation, after the tool was applied to apilot sample of the study population and outside its sample. table (2) shows the values of the stability coefficients Total degree and fields: 


\section{TABLE (2): RELIABILITY COEFFICIENTS OF THE STUDY INSTRUMENT DOMAIN \\ STUDENT \\ TEACHER \\ TECHNICAL \\ TOTAL
0.85
0.92
0.95 \\ 0.93}

Data in Table (2) shows that the total reliability reached (0.95) and for the fields it was between $(0.85-$ 0.92 ), and this indicates the reliability of the instrument and its stability.

\subsubsection{STATISTICAL TREATMENT:}

To answer the study questions, statistical treatments were performed using the Statistical Package for Social Sciences (SPSS), as follows:

1. To answer the first question, Pearson correlation coefficient and multiple regression analysis were extracted to test the validity of the study model, and the effect of the independent variable on the dependent variable.

2. VIF (Variance Inflation Factory) and the Tolerance test to ensure that there is no high multi collinearity between the independent variables.

3. (Skewness) test to ensure that the data follows a normal distribution.

4. Scheffe' post-comparison test to detect the direction of differences according to the educational platform variable.

5. To verify the reliability of the study instrument, Cronbach's coefficient was used.

6. To answer the second question "The arithmetic means and standard deviations were extracted

7. To answer the third question, a multiple analysis of variance was performed. (Multiple Anova).

8. To describe the characteristics of the study sample, frequencies and percentages were extracted.

\subsection{STUDY RESULTS AND DISCUSSION:}

TO TEST THE VALIDITY OF THE FIRST HYPOTHESIS, WHICH STATES:

1.WAS THERE A STATISTICALLY SIGNIFICANT EFFECT AT THE LEVEL (0.05 $\geq$ A $)$ FOR THE IMPACT OF MANAGING DISTANCE LEARNING EDUCATIONAL PLATFORMS ON SECONDARY STAGE STUDENTS IN ACADEMIC ACHIEVEMENT IN CHEMISTRY ?

Before starting to apply regression analysis to test the impact of distance learning educational platformson students in the secondary stage based on their academic achievement, the researchers conducted some tests, in order to ensure that the data fit the assumptions of the regression analysis, and it was confirmed that there was no high correlation between the independent variables byusing the variance inflation test (VIF) and the allowable variance test(Tolerance) for each of the study variables, taking into account that the coefficient of variance inflation did not exceed the value (10) and the value of the permissible variance test was greater than $(0.05)$. It was also made sure that the data followed the normal distribution by calculating the Skewness coefficient, bearing in mind that the data follow the normal distribution if the Skewness coefficient value approaches from $(0)$. Table No. (3) shows the results of these tests.

TABLE NO. (3): THE VARIANCE INFLATION FACTOR, THE PERMISSIBLE VARIANCE, AND THE SKEWNESS FACTOR TEST.

$\begin{array}{cccc}\text { INDEPENDENT VARIABLES } & \text { VIF } & \text { TOLERANCE } & \text { SKEWNESS } \\ \text { STUDENT- RELATED ASPECTS } & 1.264 & 0.457 & 0.288 \\ \text { TECHNICAL- RELATED ASPECTS } & 1.835 & 0.647 & 0.265 \\ \text { TEACHER- RELATED ASPECTS } & 1.542 & 0.590 & 0.316\end{array}$

We note that the coefficient of variance inflation test values for all variables were less than 10 and range between (1.635-1.635). 1.842), and that the permissible variance test values ranged between $(0.457-0.647)$, which was greater than (0.05), and this was an indicator that there was no high correlation between the independent variables, and the data has been confirmed to follow the normal distribution by calculating the skewness coefficient, where the values approached the value (0), and the validity of the model was verified and table No. (4) shows the results.

TABLE NO. (4):RESULTS OF THE ANALYSIS OF VARIANCE FOR REGRESSION TO CHECK THE VALIDITY OF THE MODEL.

\begin{tabular}{|c|c|c|c|c|c|c|}
\hline $\begin{array}{l}\text { DEPENDENT } \\
\text { VARIABLE }\end{array}$ & SOURCE & R2 & $\begin{array}{l}\text { SUM OF } \\
\text { SQUARES }\end{array}$ & $\begin{array}{l}\text { MEAN OF } \\
\text { SQUARES }\end{array}$ & $\begin{array}{c}\text { CALCULATED } \\
\text { F VALUE }\end{array}$ & $\begin{array}{c}\text { LEVEL OF F } \\
\text { SIGNIFICANCE }\end{array}$ \\
\hline \multirow[t]{2}{*}{ ICHIEVEMENT } & REGRESSION & 0.648 & 81.967 & 34.514 & \multirow[b]{2}{*}{132.614} & $0.00 * *$ \\
\hline & ERROR & & 41,083 & .2460 & & \\
\hline
\end{tabular}

** STATISTICALLY SIGNIFICANT AT THE LEVEL OF SIGNIFICANCE $(\alpha \geq 0.01)$.

Table No. (4) shows the reliability and the validity of the model for prediction, in terms of the value of 
calculated (F) and the level of significance accompanying it at the level of significance $(\geq \alpha 0.01)$, where The impact of managing distance learning educational platforms on secondary stage students as a whole accounted for $(64.8 \%)$ of the variance in the total dependent variable (academic achievement), and this result indicated the existence of an effect of distance learning on secondary students' academic achievement, and accordingly a multiple regression analysis test was conducted to test the effect of the dimensions of the independent variable (distance learning) on academic achievement, and Table (5) shows the results of that.

TABLE NO. (5):THE RESULTS OF THE MULTIPLE REGRESSION ANALYSIS TO TEST THE EFFECT OF THE DIMENSIONS OF THE INDEPENDENT VARIABLE NO EFFECT PLATFORM MANAGEMENT IN LEARNING AND EDUCATION DISTANCE LEARNING ACHIEVEMENT FOR SECONDARY SCHOOL STUDENTS IN CHEMISTRY.

$\begin{array}{lccccc}\begin{array}{l}\text { INDEPENDENT } \\ \text { DIMENSION }\end{array} & \text { BETA } & \begin{array}{c}\text { STANDARD } \\ \text { ERROR }\end{array} & \text { BETA } & \begin{array}{c}\text { CALCULAT } \\ \text { E (T) VALUE }\end{array} & \begin{array}{c}\text { LEVEL OF (T) } \\ \text { SIGNIFICANC } \\ \text { E }\end{array} \\ \text { CHNICAL- RELATED } & 0.089 & 0.078 & 0.163 & 2.453 & 0.245\end{array}$

$\begin{array}{cccccc}\text { TECHNICAL- RELATED } & 0.089 & 0.078 & 0.163 & 2.453 & 0.245 \\ \begin{array}{c}\text { ASPECTS } \\ \text { STUDENT- RELATED } \\ \begin{array}{c}\text { ASPECTS } \\ \text { TEACHER- RELATED }\end{array}\end{array} & 0.330 & 0.074 & 0.306 & 5.856 & 0.000^{*} \\ \end{array}$

ASPECTS

It was evident from the statistical results presented in Table (5), and from the follow-up of the (Beta), and (t) test that the following sub-variables related to (the aspects associated with the student, the aspects associated with the teacher) had an effect on academic achievement, in terms of (Beta) coefficients for these variables as in the table and in terms of the increase in calculated $(\mathrm{t})$ values from their tabular value at significance level $(\alpha 0.05$ $\geq$ ) while there was no statistically significant effect of the sub-variable (aspects related to the technical aspect) on academic achievement.

To determine the importance of each independent variable in contributing to the mathematical model, which represents the impact of students' integration in distance learning represented by its aspects (Aspects related to the technical aspect, aspects related to the student, aspects related to the teacher) on academic achievement, a progressive multiple regression analysis was conducted, and Table No.(6) shows the results of that.

TABLE (6):THE RESULTS OF A STEPWISE MULTIPLE REGRESSION ANALYSIS TO PREDICT ACADEMIC ACHIEVEMENT THROUGH THE DIMENSIONS OF THE EFFECTIVENESS OF DISTANCE LEARNING EDUCATIONAL PLATFORMS ON STUDENTS IN IN SECONDARY STAGE IN CHEMISTRY.

\section{THE ORDER OF INDEPENDENT \\ ELEMENTS ENTRANCE INTO PREDICTION EQUATION}

TEACHER- RELATED ASPECTS

STUDENT- RELATED ASPECTS

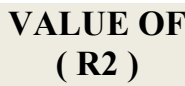

0.5264

0.6587

\section{CALCULATE \\ (T) VALUE}

11,843
6.789
LEVEL OF (T)

SIGNIFICANCE

$0.000^{*}$

$0.000 *$

** STATISTICALLY SIGNIFICANT AT THE LEVEL $(\alpha \geq 0.05)$.

- Out of the regression equation: the aspects related to the technical aspect.

It is clear from Table No. (6), which shows the order of entry of the independent variables into the regression equation, that teacher - related aspects "Aspects related to the teacher," was ranked first and accounted for $(.52 .64 \%)$ of the variance in the dependent variable, followed by the dimension of "aspects associated with the student" alongside with the dimension of "aspects associated with the teacher") accounted for $(65.87 \%)$ of the variance in the dependent variable, and the variable "aspects related to the technical aspect" came out of the regression equation.

Researchers believe that high academic achievement needs a teacher with professional adequacy and has information and is able to convey it to the student in a clear language, and its acquisition is better if the teacher is able to use teaching strategies. The acquisition of concepts and the ability to employ them for the sake of achievement needs teaching aids, so the teacher's use of educational means improves academic achievement. To improve student's achievement, the teacher is required to take into account individual differences in that a student understands the lesson rapidly while another one needs more explanation. This result may also be explained based on the high motivation to learn and motivation to improve their achievement.

1. DISCUSSION THE RESULTS OF THE SECOND QUESTION WHICH READS: "WHAT IS THE EFFECT OF MANAGING DISTANCE LEARNING EDUCATIONAL PLATFORMS IN JORDAN? to answer this question, the arithmetic means and standard deviations of the responses of the study sample were extracted, and Table (7) shows the results of that. 
TABLE(7): ARITHMETIC MEANS, STANDARD DEVIATIONS, AND RANK OF THE IMPACT OF MANAGING EDUCATIONAL PLATFORMS ON SECONDARY STAGE STUDENTS DURING DISTANCE LEARNING WITH ITS VARIOUS PLATFORMS.

\begin{tabular}{lccccc}
\multicolumn{1}{c}{ DOMAINS } & $\begin{array}{c}\text { ARITHMETIC } \\
\text { MEAN }\end{array}$ & $\begin{array}{c}\text { STANDARD } \\
\text { DEVIATION }\end{array}$ & RANK & LEVEL \\
STUDENT- RELATED ASPECTS & 3.89 & 0.49 & 2 & MIDDLE \\
TECHNICAL- & RELATED & 3.14 & 0.53 & 1 & HIGH \\
ASPECTS & 3.78 & 0.58 & 3 & MIDDLE \\
TEACHER- RELATED ASPECTS & 3.66 & 0.69 & - & HIGH \\
TOTAL & & &
\end{tabular}

the researchers explain this result based on the interest of the Ministry of Education and students in the secondary stage, especially the second secondary stage, which is one of the crucial stages in deciding the future of the student. This result also accounts for the Ministry of Education seriousness and adherence to student's favor by assurance the continuity of teaching during corona pandemic which is the most serious crises that the world has faced in the modern era, and the use of distance learning indicates the advanced technological level of the use of educational technology in Jordan.

Distance learning has proven to be one of the best alternatives that maintain the continuity of education during crises. The researchers explain this result based on the attractiveness of distance learning, which enabled students to interact to gather .This result shows that students are able to deal technically with educational platforms, and they have the means to follow them, and their positive attitude towards these platforms stems from teacher's competence and their ability to communicate information to the student, attract his attention and stimulate his motivation to learn using teaching strategies in an easy, clear and understandable language, taking into account the students' capabilities and mental abilities. Distance learning in itself is an educational strategy that provides information to the student while in a state of psychological stability and physical comfort. Furthermore, teachers' consideration of students' material and technical conditions, and dealing with the problems that arise during the use of the platforms has increased the students' integration. The assignments are not immediate and there is a space of time for the student to send to the teacher at any time. It allows the student to communicate with the teacher and discuss anything at any time. The educational platforms enable the teacher to provide the content he wants freely the learner at home without the intervention of the supervisor or the administration due to the freedom offered by educational platforms to the student.

1. WERE THERE ANY STATISTICALLY SIGNIFICANT DIFFERENCES AT THE LEVEL $(0.05 \geq A)$ FOR THE IMPACT OF MANAGING DIFFERENT EDUCATIONAL PLATFORMS ON SECONDARY STAGE STUDENTS DURING THE DISTANCE LEARNING WITH ITS DIFFERENT PLATFORMS ATTRIBUTED TO THE VARIABLES (GENDER, GRADE, EDUCATIONAL PLATFORM )?

To answer this question, the arithmetic means and standard deviations of the estimates of secondary stage students were extracted during the distance learning .According to the study variables (gender, grade, educational platform) . Table No. (8) shows the results of that.

TABLE (8): ARITHMETIC MEANS AND STANDARD DEVIATIONS OF SECONDARY STAGE STUDENTS DURING DISTANCE LEARNING STUDIES ACCORDING TO STUDY VARIABLES.

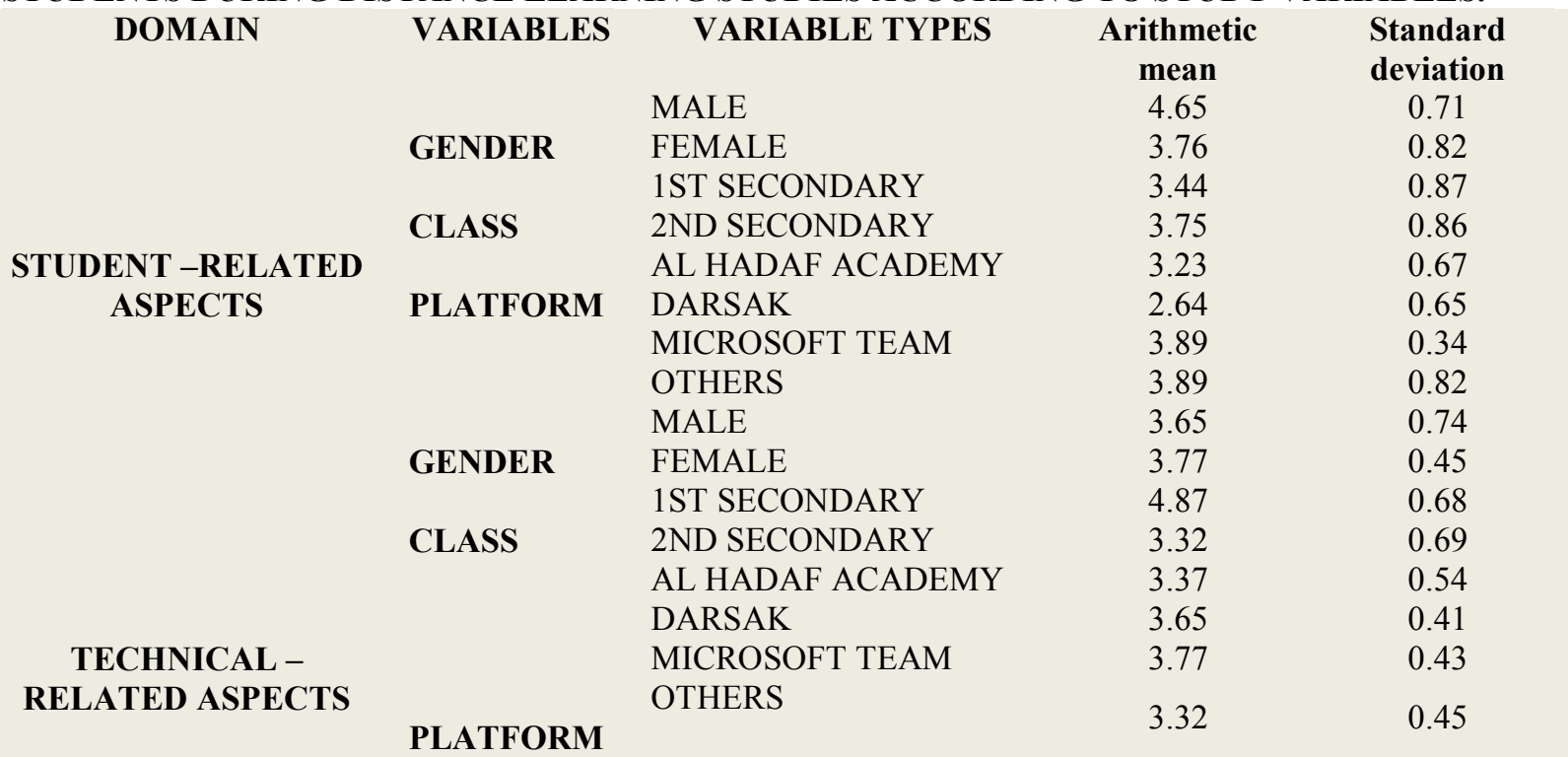




\begin{tabular}{|c|c|c|c|c|}
\hline \multirow{16}{*}{$\begin{array}{c}\text { TEACHER - RELATED } \\
\text { ASPECTS }\end{array}$} & \multirow[b]{2}{*}{ GENDER } & MALE & 3.44 & 0.97 \\
\hline & & FEMALE & 3.60 & 0.46 \\
\hline & \multirow{3}{*}{ CLASS } & 1ST SECONDARY & 3.33 & 0.88 \\
\hline & & 2ND SECONDARY & 3.75 & 1.03 \\
\hline & & AL HADAF ACADEMY & 4.40 & 0.29 \\
\hline & \multirow{4}{*}{ PLATFORM } & DARSAK & 3.47 & 0.46 \\
\hline & & MICROSOFT TEAM & 3.44 & 0.51 \\
\hline & & OTHERS & 3.48 & 0.53 \\
\hline & & MALE & 3.63 & 0.99 \\
\hline & \multirow[t]{2}{*}{ GENDER } & FEMALE & 3.74 & 0.61 \\
\hline & & 1ST SECONDARY & 3.59 & 0.51 \\
\hline & \multirow[t]{2}{*}{ CLASS } & 2ND SECONDARY & 3.79 & 0.80 \\
\hline & & AL HADAF ACADEMY & 4.35 & 0.22 \\
\hline & \multirow{3}{*}{ PLATFORM } & DARSAK & 3.54 & 0.33 \\
\hline & & MICROSOFT TEAM & 3.53 & 0.35 \\
\hline & & OTHERS & 3.51 & 0.36 \\
\hline
\end{tabular}

The data in Table (8) indicate that there were apparent differences in the estimates of secondary stage students for the impact of managing educational platforms during the distance learning according to the study variables, and to detect whether these differences were significant and statistically significant, the triple analysis of variance was applied, and Table (9) shows the results of that.

TABLE (9): MULTIPLE VARIANCE ANALYSIS RESULTS TO DETECT DIFFERENCES IN DISTANCE LEARNING PLATFORM MANAGEMENT EFFECT ACCORDING TO THE VARIABLES OF THE STUDY.

\begin{tabular}{|c|c|c|c|c|c|c|}
\hline DOMAIN & $\begin{array}{l}\text { SOURCE OF } \\
\text { VARIANCE } \\
\text { GENDER }\end{array}$ & $\begin{array}{c}\text { SUM OF } \\
\text { SQUARES } \\
7.387\end{array}$ & $\begin{array}{c}\text { ( D. F ) } \\
1\end{array}$ & $\begin{array}{c}\text { MEAN OF } \\
\text { SQUARES } \\
7.387\end{array}$ & $\begin{array}{c}\text { ( F ) } \\
\text { VALUE } \\
* 44,221\end{array}$ & $\begin{array}{c}\text { SIGNIFICANC } \\
\text { ( E ) LEVEL } \\
0.000^{*}\end{array}$ \\
\hline \multirow[t]{5}{*}{ STUDENT } & CLASS & 5.836 & 1 & 5.836 & *26.614 & $0.000 *$ \\
\hline & $\begin{array}{l}\text { EDUCATIONAL } \\
\text { PLATFORM }\end{array}$ & 16.745 & 4 & 4.635 & *33.698 & $0.000 *$ \\
\hline & ERROR & 108.030 & 2012 & 0.113 & & \\
\hline & TOTAL & 15086,620 & 2019 & & & \\
\hline & GENDER & 0.852 & 1 & 4.624 & *9.860 & $0.000 *$ \\
\hline \multirow[t]{4}{*}{ TECHNICAL } & CLASS & 14.632 & 1 & 14.632 & *119.725 & $0.000 *$ \\
\hline & $\begin{array}{l}\text { EDUCATIONAL } \\
\text { PLATFORM }\end{array}$ & 30.334 & 4 & 9.651 & $* 89.420$ & $0.000 *$ \\
\hline & ERROR & 76.673 & 2012 & 0.072 & & \\
\hline & TOTAL & $15 \operatorname{th} 634.582$ & 2019 & & & \\
\hline \multirow{7}{*}{ TEACHER } & GENDER & 4.624 & 1 & 4.624 & *12.62 & $0.000^{*}$ \\
\hline & CLASS & 14.873 & 1 & 14.873 & $* 76.476$ & $0.000 *$ \\
\hline & $\begin{array}{l}\text { EDUCATIONAL } \\
\text { PLATFORM }\end{array}$ & 42.467 & 4 & 8.583 & $* 70.280$ & $0.000^{*}$ \\
\hline & ERROR & 97.786 & 2012 & 0.145 & & \\
\hline & TOTAL & 17653.674 & 2019 & & & \\
\hline & GENDER & 2. 364 & 1 & 2.364 & $* 31.871$ & $0.000^{*}$ \\
\hline & CLASS & 7.536 & 1 & 7.536 & $* 152.562$ & $0.000^{*}$ \\
\hline \multirow[t]{3}{*}{ TOTAL } & $\begin{array}{l}\text { EDUCATIONAL } \\
\text { PLATFORM }\end{array}$ & 30.643 & 4 & 7.243 & *104.734 & $0.000 *$ \\
\hline & ERROR & 47.674 & 2012 & 0.087 & & $0.000^{*}$ \\
\hline & TOTAL & 19365.447 & 2019 & & & $0.000 *$ \\
\hline
\end{tabular}

The data in Table (9) indicate that there were statistically significant differences at the level of significance $(\alpha \leq 0.05)$ in the students' estimates, the estimates of secondary stage students during the distance learning according to the variables (gender, grade, educational platform) at the total level as well as at the level of each of the domains, and to detect in favor of which the differences are due according to the gender variable, the class ,there was reference to the arithmetic means in Table (8), which showed that the differences according to the gender variable were in favor of females while the differences according to the academic grade were in favor of the second secondary students. In order to detect in favor of whom the differences are due, according to the educational platform variable, the scheffe test was used for post comparisons and Table No. (10) shows the results of that. 


\begin{tabular}{|c|c|c|c|c|c|c|}
\hline DOMAIN & $\begin{array}{c}\text { ARITHMETIC } \\
\text { MEAN }\end{array}$ & $\begin{array}{l}\text { EDUCATIONAL } \\
\text { PLATFORM }\end{array}$ & DARSAK & $\begin{array}{l}\text { MICROSOFT } \\
\text { TEAM }\end{array}$ & $\begin{array}{l}\text { AL HADAF } \\
\text { ACADEMY }\end{array}$ & OTHERS \\
\hline \multirow{5}{*}{$\begin{array}{l}\text { STUDENT } \\
\text { DOMAIN }\end{array}$} & 4.28 & $\begin{array}{l}\text { AL HADAF } \\
\text { ACADEMY }\end{array}$ & $0.65^{*}$ & $0.62 *$ & $0.69 *$ & $0.72 *$ \\
\hline & 3.63 & DARSAK & - & -0.03 & 0.04 & 0.07 \\
\hline & 3.66 & $\begin{array}{l}\text { MICROSOFT } \\
\text { TEAM }\end{array}$ & & - & 0.07 & 0.1 \\
\hline & 3.56 & OTHERS & & & & - \\
\hline & 4.36 & $\begin{array}{l}\text { AL HADAF } \\
\text { ACADEMY }\end{array}$ & $0.84 *$ & $0.86^{*}$ & $0.85 *$ & $0.86^{*}$ \\
\hline \multirow{5}{*}{$\begin{array}{l}\text { TECHNICA } \\
\text { L DOMAIN }\end{array}$} & 3.52 & DARSAK & - & 0.02 & 0.01 & 0.02 \\
\hline & 3.50 & $\begin{array}{l}\text { MICROSOFT } \\
\text { TEAM }\end{array}$ & & \multirow[t]{2}{*}{-} & \multirow[t]{2}{*}{-0.01} & 0.01 \\
\hline & 3.50 & OTHERS & & & & - \\
\hline & 4.40 & $\begin{array}{l}\text { AL HADAF } \\
\text { ACADEMY }\end{array}$ & \multirow[t]{2}{*}{$0.93 *$} & $0.96^{*}$ & $0.91 *$ & $0.92 *$ \\
\hline & 3.47 & DARSAK & & 0.03 & -0.02 & -0.01 \\
\hline \multirow[t]{3}{*}{$\begin{array}{l}\text { TEACHER } \\
\text { DOMAIN }\end{array}$} & 3.44 & $\begin{array}{l}\text { MICROSOFT } \\
\text { TEAM }\end{array}$ & & \multirow[t]{2}{*}{ - } & \multirow[t]{2}{*}{-0.05} & -0.04 \\
\hline & 3.48 & OTHERS & \multirow[b]{2}{*}{$0.81 *$} & & & - \\
\hline & 4.35 & $\begin{array}{l}\text { AL HADAF } \\
\text { ACADEMY }\end{array}$ & & $0.82 *$ & $0.82 *$ & $0.84 *$ \\
\hline \multirow[t]{2}{*}{ TOTAL } & 3.54 & DARSAK & - & 0.01 & 0.01 & 0.03 \\
\hline & $\begin{array}{l}3.53 \\
3.51\end{array}$ & $\begin{array}{l}\text { MICROSOFT } \\
\text { TEAM } \\
\text { OTHERS }\end{array}$ & & - & 0 & $\begin{array}{c}0.02 \\
-\end{array}$ \\
\hline
\end{tabular}

The data in the table (11) indicated that there were statistically significant differences at the level of each dimension and the total dimension between the estimates of students who use Darsak platform and the rest of the other platforms in favor of Darsak platform.

\subsection{RECOMMENDATIONS:}

IN LIGHT OF THE RESULTS, THE FOLLOWING RECOMMENDATIONS CAN BE MADE:

1. Encouraging students to pursue distance learning that is offered by educational platforms, as it is the best alternative that maintains the continuity of the educational process during crises.

2. The necessity of training students and teachers to use distance learning technology, such as educational platforms, and to deal with problems that occur during the lesson on e-learning platforms to solve the deadlock of teaching and understanding chemistry .

3. The need to expand the use of educational technology, and to provide free internet packages to students to enable those who are unable to follow what is offered on educational platforms in terms of explanation and simplification of the content of the chemistry topic.

4. conducting more studies on the effect of management different educational platforms in the educational process for secondary stage in chemistry and the extent to which students benefit and integrate with them in the directorates of education and other educational stages to benefit from the results of the current study and its generalizations.

\section{REFERENCES:}

Al-Qathami, Abdullah. (2013). The contribution of distance learning on achieving the objectives of the Islamic University of Madinah: A proposed conception from the point of view of the faculty members, an unpublished doctoral thesis, the Islamic University of Madinah.

Al-Azzam, Maysam. (2015). Quality assurance in open and distance learning. Journal of Culture and Development. (15), 1-24.

Al-Enazi, Shima Salem. (2019). The impact of school electronic platforms in enhancing the values of citizenship among Saudi secondary stage students. Al-Quds Open University . (7), 20-36.

Miqdadi (2020), Perceptions of secondary stage students in government schools in Jordan for using distance learning in light of the Corona crisis and its developments. The Arab Journal for Scientific Publishing. (19), 96- 114 .

Koch, Buheji, Abdulkarim (2020), Distance learning in emergency situations (Bahrain, Iraq, Russia) during the 
COVID-19 pandemic. International Journal of Human Systems Management: 44.

Windscchitl, M. (1999).Framing constructivism in practice as the negotiation of dilemmas: An analysis of the conceptual'pedagogical'cultural, and political challenges facing teachersof Educational Research,72(2),131 - 175.

\section{THE AUTHORS:}
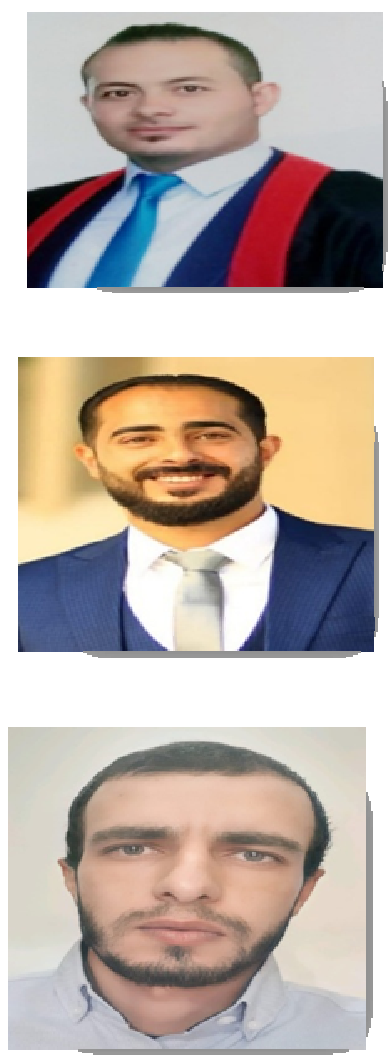

Dr. BILAL JAFFAL MOHAMMAD ABUKDEIRI

belal abukdyre@yahoo.com

JORDAN - ALKARAK

Mr. HUTHAIFA AS'SD MOHAMMAD ALTARAWNEH

Huthyfahat321@gmail.com

JORDAN - ALKARAK

Mr. AHMAD TAHSEEN MOUSA ALTARAWNEH

Ahmadttara@gmail.com

JORDAN - ALKARAK 